\title{
Transition to a Market Economy: Some First Principles
}

\author{
Allan H. MELTZER \\ Graduate School of Industrial Administration, Camegie Mellon \\ University, Schenloy Park, Pittsburgh, Pennsylvania 15213- \\ 3890, USA
}

To work efficiently, a market system requires institutions such as private property, legal and accounting systems, and a monetary framework. These institutions need not be in place, but the structure should be agreed upon so that market participants can value assets. The peper concentrates on decisions about the choice of monetary arrangements, price and wage setting. Several countries in Eastern Europe have adopted fixed exchange rates and wage controls. The paper argues that the combination is generally inconsistent; only one relative price can be fixed. Attempts to fix wage rates and the exchange rate increases uncertainty and imposes an excess burden. The paper proposes fixed exchange rates for East European countries and development of a clearing union. In contrast to time phased programs of liberalization, the paper argues that structural changes should be announced and price, wage, budget, and monetary reforms should be made simultaneousty.

Keywords: Prices, institutional structure, incentives, ownership, property rights, exchange rate, excess burden, currency boards, payments union, inconsistency, indeterminacy

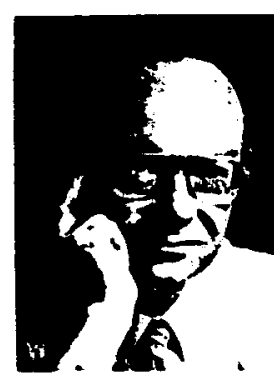

Allan H. Meltzer is University Professor of Political Economy and Public Policy at Carnegie Mellon University and Viaiting Scholar at the American Enterprise Inatitute. He served as an Acting Member of the President's Council of Economic Advisers in 1988-89. He is co-founder and Chairman of the Shadow Open Market Committee, a group of economists that comment semi-annually on economic policy issues. His reputation in the field of money and capital markets has brought frequent assignments with Congressional committees, as a consultant to the U.S. Treasury Department, the Board of Governors of the Federal Reserve System and to foreign governments and central banks. Currently, he is Honorary Adviser to the Institute for Monetary and Economic Studies of the Bank of Japan.

IOS Press

Human Systems Management 12 (1993) 281-288

\section{Introduction}

In abstract economic theory, a market economy is a set of prices and quantities at which individuals transact. Economists have elaborated a set of conditions under which the set of prices and quantities is an equilibrium. It is widely recognized that the process driving the economy to its equilibrium requires an institutional structure that gives producers an incentive to offer more at higher prices and for buyers to reduce amounts demanded as prices rise.

A main problem for countries in transition from a command to a market economy is to provide the institutions under which the market process can function as expected. At present, economists and other social scientists can say little about the relative importance of particular institutions for obtaining the harmonious, productive outcomes found in market economies that work well.

International agencies such as the International Monetary Fund (IMF) the World Bank and the European Bank that have responsibility for advice and lending to Eastern Europe often neglect the role of institutions. The IMF applies principles learned from theory and experience mainly in developing countries. This experience, like the theory, must take account of institutional structure.

The importance of institutional arrangements can be illustrated in three examples. First is the effect of removing price controls. Second and third are decisions about monetary or exchange rate policy and about wages.

Dr. Meltzer's writings have appeared in numerous journals, including the business preas here and abroad. He is the author of several books and more than 200 papers on economic theory and policy. Currently, he is co-editor of the Camegio-Rochester Conference Series on Public Policy, and Aseociate Editor of several journals including the Joumal of Monetary Economics.

In 1983 Profeseor Meltzer received a medal for distinguished profeseitonal achievement from the University of California, LOS Angeles. He is a past president of the Western Economic Association and a Fellow of the National Association of Business Economists. 


\section{Removing Price Controls}

In a market economy, price controls distort the use of resource in several ways. In the case most applicable to Eastern Europe before reform, most prices were fixed by some authority below the level at which the market would clear. Suppliers offered less than in a market economy, and buyers demanded more. Waiting lines, ration cards, disappointment, or other non-price systems limited the amount sold to the amount offered. In Russia and Poland particularly, black markets functioned actively.

Removing controls in a market economy removes these distortions. Price rise and output increases. In the now famous West German reform of 1948 , which some hoped partially to replicate in Eastern Europe, producers anticipated the end of controls by increasing inventories. When controls were lifted, goods became available quickly.

Everyone familiar with Eastern Europe comments on the abundance of goods available after price reform. The difference with West Germany, and many similar experiences in market economies, is that domestic production did not respond quickly to the market signal. Many of the goods that became available were imports. The response of production was slow and weak because state owned industries had not been sold and, in most Eastern European countries, no plan or program had been adopted for selling the firms.

There was a market without supporting market institutions. State owned firms and the officials that controlled them lacked the incentives open to private owners to profit from anticipating or responding to higher prices by increasing output. They lacked also strong incentives to compete with Western firms by improving the quality of the products offered. In many cases, the managers' most profitable opportunity was to sell their enterprises assets.

Market responses depend on ownership, and reward structures that furnish the incentives by which individual actions achieve desirable social outcomes. Ownership rights are one of the institutions that induce market economies to operate more efficiently than command economies.

Ownership is not the sole requirement. Contracts
- and rules for their enforcement - accounting systems - and rules encouraging honest reporting - financial systems - and rules for repayment - a commercial code - and courts to enforce it - these and other institutional arrangements of the market economy are necessary for orderly functioning of a market system. Without such arrangements, trade and exchange are difficult, delivery is uncertain, assets valuations are problematic, and ownership rights are unclear.

The German government extended German law, accounting, valuation, and financial systems to the former East Germany. Much property did not have clear title. Former owners had claims. This delayed and, at times, prevented property transfers and investment. This was not the only problem; prospective wage increases were above any likely productivity gains, as I discuss below. Nevertheless, the absence of clearly established property rights delayed development of a private sector particularly in manufacturing. In contrast, enterprises engaged in trade, services and small scale production often developed rapidly. Ownership and control of these enterprises was more easily achieved and, in Hungary and to a lesser extent in Poland, had preceded the end of communism.

The problem was much more serious in the former Soviet Union where development of market institutions was slow or non-existent. The IMF at first concentrated on the reforms it understood without questioning whether they would work without property rights and the institutional conditions required for a market system. The removal of price controls brought market clearing prices, reduced black markets, and increased efficiency. It did not generate a large response of production. The reason is that the incentives faced by managers were much more mixed than the incentives that similar price signals would give in a market economy. The statistics that are available are of questionable value. They show declining industrial production in all countries of Eastern Europe. The reported decline accelerated in most countries until the middle of 1992. Nevertheless, private firms in Poland increased output $42 \%$ in 1991 whereas reported output fell by more than $10 \%[6,7]$.

The difficulty of separating the one-time price effects of removing controls from the effects of infla- 
tionary monetary policy also made price signals difficult to read. Costs of production changed with market prices, and mistakes in monetary and wage arrangements added to the confusion.

\section{The Monetary System}

The monetary and financial systems are among the main institutions required for a market economy and for transition from a command to a market economy. Establishing a monetary system involves a choice between a fixed or fluctuating exchange rate. The former relinquishes control of the domestic money stock and price level. The latter relinquishes control of the exchange rate. Economic theory does not give an unconditional answer as to which is preferable, and it does not give a precise answer about the conditions under which a fixed or fluctuating exchange rate is preferable.

For the former socialist countries during the transition, there are some unique problems affecting the choice. Information is lacking about current positions. Future growth, inflation, demand for money and trade balance are more than usually uncertain. A policy of letting exchange rates fluctuate while trying to set money growth in relation to growth of real income at zero (or constant) inflation presupposes that there are adequate measures of real and nominal output growth, prices, and inflation. In practice, this is far from true. Typically, output is measured in the state industries. Private production and the output of new enterprises is not counted. Although markets grow in importance during the transition, and some estimates suggest they now account for more than $40 \%$ of GDP in Poland and Hungary, private production and other market transactions are not fully recorded in official statistics. Prices of many individual goods and services have been set arbitrarily, so a transaction weighted average of prices or rates of price change is not representative of the basket of goods and services currently available and does not reflect relative scarcities and demands. For these reasons alone, it is difficult to achieve non-inflationary money growth either by a fixed or adaptive rule based on past values of prices and output or by dis- cretionary adjustment to past or anticipated future values of these variables.

Transitional problems in controlling money do not end there. Socialist economies do not have developed banking and credit systems, and they do not offer diversified forms of wealth that individuals hold in their portfolios. Financial assets, particularly money and savings accounts, dominate wealth holding. As these countries develop and privatize wealth, the demand for money changes. Some of the changes are permanent, and some are transitory. A central bank trying to control money under these circumstances would have few reliable guidelines about the demand for money, prices and output. It seems likely, therefore, that variability of money growth would be much larger than in developed, market economies, and there would be relatively high uncertainty about future prices and inflation. Such uncertainty would be reflected in real rates of interest and in the variability of exchange rates.

Additional uncertainty would arise from budget finance. The temptation to finance part of the budget at the central bank or provide credit subsidies for favored borrowers is present in many economies. Further, the knowledge that a central bank can finance deficits or offer credit subsidies encourages the government and parts of the public to act so as to make such choices likely. Experience suggests that the temptation to deviate from a noninflationary course is difficult to avoid; experience in Russia and Poland shows that it is difficult to avoid pressures to provide credit by printing money. The public recognizes the problem, so it will be reflected in a risk premium in interest rates. Real interest rates will be higher and the capital stock lower than attainable values.

Real exchange rates appear to be more variable under fluctuating exchange rates. Mussa's study of the comparative variability of ex post real, bilateral exchange rates in countries with fixed and fluctuating exchange rates found that the shift to fluctuating rates in the 1970s uniformly raised measures of ex post variability of real exchange rates [4]. His measure of variability was from 8 to 80 times higher under fluctuating rates. Studies of multilateral real rates reduce the amount of the additional variabili- 
ty to a factor 3 to 5 . All of the additional variability does not constitute excess burden for the country, but it would not be surprising that a fixed exchange that is expected to last would reduce uncertainty.

One objective for the former socialist countries is integration into the world economy. If forward markets for their currencies arise, they are likely to have relatively large risk premia and wide spreads between buying and selling rates, given the uncertainty about future policies and future development. Without much history on which to base anticipations, greater weight is placed on current observations; consequently many changes are likely to be treated as permanent until new information arrives. A fixed exchange rate system avoids some of these costs of information, particularly if the fixed exchange rate is expected to remain fixed.

There is an additional advantage of a fixed exchange rate. Countries can achieve both relatively low inflation and low (zero) variability of nominal exchange rates by fixing their currency to a country with low inflation. No country acting alone can achieve both internal and external stability - stability of the domestic price level and exchange rate stability. The presence of countries with low inflation rates permits the former socialist countries to achieve a relatively stable price level at low cost while gaining the benefit of a fixed exchange rate.

Some of the uncertainty associated with a rule setting nominal money growth equal to the average growth of output could be avoided by fixing the nominal stock of base money issued by the central bank once-and-for-all. The market would adjust individual prices and the price level to the fixed stock of money. Banks and other intermediaries would produce money balances for the public using the fixed stock of base money as an input. By developing means of economizing on currency or increasing efficiency in the use of reserves, banks could expand money for a given money base, but the amount of such expansion would be limited. Prices would change in response to real shocks but inflation would be avoided. Information costs about current or prospective monetary policy would be similar to the costs under a fixed exchange rate. The exchange rate would fluctuate. If most of the external shocks to the economy are real, exchange rate changes would buffer some of the shocks, subject to the problems of information and uncertainty discussed earlier.

\section{A Currency Board}

A rule fixing the stock of money shares an important feature of the fixed exchange rate rule. There is no need for a central bank to control money in one case or the exchange rate in the other. The central bank can close down its monetary activities and limit its role to supervision and regulation. Markets would determine the price level and exchange rate in the case of a permanently fixed stock of money and would determine the quantity of money and the price level in the fixed exchange rate regime.

Both of these institutional arrangements would operate like the currency boards that have been tried in the past ${ }^{1}$. Private banks would convert domestic into foreign currency or the reverse and would exchange currency for deposits. With a fixed stock of money, the nominal exchange rate would adjust to clear the market for foreign exchange. With a fixed exchange rate, the foreign exchange market would determine the stock of money. As in a currency board system, the government would collect seigniorage by issuing a local money unit, but the amount issued would be limited in one case by the rule fixing the quantity of money and in the other by the demand for domestic money at the fixed exchange rate.

The two systems would have some common features. There would be no central bank monetary operations. Budget deficits could not be financed by money creation. Real interest rates would approach world rates.

Each system would have a common disadvantage. There would be no lender of last resort to reduce the cost of systemic shocks. If concerns about failure of a major bank induced a run to money, prices and money or exchange rates and money would have to absorb the shock. Banks or the government would have limited ability to buffer the shock by borrowing abroad. The public would experience the effects on output and income.

1 Steve Hanke has written extensively advocating a currency board for Russia, e.g., in [2]. See also [5]. As noted in Table 1, Estonia has established a currency board. 
Table 1

\begin{tabular}{|c|c|c|c|}
\hline Country & $\begin{array}{l}\text { Exchange } \\
\text { Rate System }\end{array}$ & Outcome & $\begin{array}{l}\text { Deficit/GDP } \\
\% \text { (date) }\end{array}$ \\
\hline $\begin{array}{l}\text { Bulgaria } \\
\text { Czech Republic } \\
\text { Estonia } \\
\text { Hungary }\end{array}$ & $\begin{array}{l}\text { floating } \\
\text { fixed } \\
\text { currency board } \\
\text { fixed }\end{array}$ & $\begin{array}{l}\text { stable } \\
\text { adopted } 1992 \\
\text { devalued twice } \\
\text { in } 1992\end{array}$ & $\begin{array}{c}-14.9(1991) \\
+1 \quad(1992 \mathrm{HI}) \\
0 \quad(1992 \mathrm{HI}) \\
-4.1(1991)\end{array}$ \\
\hline $\begin{array}{l}\text { Latvia } \\
\text { Poland }\end{array}$ & $\begin{array}{l}\text { fixed to ECU } \\
\text { fixed } \\
\text { now crawling peg }\end{array}$ & $\begin{array}{l}\text { adopted } 1992 \\
\text { devalued } 1991\end{array}$ & $\begin{array}{l}-3.5(1892 \mathrm{HI}) \\
-3.4(1991)\end{array}$ \\
\hline Romania & $\begin{array}{l}\text { managed float } \\
\text { two-tiered market }\end{array}$ & & $+2.1(1991)$ \\
\hline
\end{tabular}

Source: [6].

The fixed exchange rate system with a currency board would achieve stability of the exchange rate and price stability if inflation remains low abroad. I believe either system would provide greater stability and less inflation than what has been established in Russia and some other countries or is likely to come.

No monetary system will achieve price stability or avoid inflation unless the budget deficit is limited. Table 1 shows some of the many experiments that have been tried in Eastern Europe and the most recent data for the budget deficit as a percentage of GDP. It is too early to judge the results, but it is clear already that some countries with relatively large deficits have failed to keep exchange rates fixed.

\section{A Payments Union}

Much of the trade within the states of the former Soviet Union and between these states and other countries of Eastern Europe has been disrupted. Most transactions are now made in convertible currencies, principally the dollar and the mark. The volume of exports to Western countries remains small in most cases. This limits imports and trade within the former Comecon bloc, disrupts former supply relationships and reduces output.

A payments union would permit each of the countries to reduce the amount of foreign exchange required for payment of intercountry transactions. In the 1950s, a payments union in Western Europe facilitated trade and reduced the amount of foreign exchange to finance transactions. Instead of settling each transaction separately, payments would be consolidated so only net balances would be transferred. Western governments or the IMF should encourage this type of institutional change by offering to establish and sustain a payments union for the states of the former Soviet Union and between these states and other East European countries.

\section{Wages}

Recent arguments for wage controls during the transition appeal to so-called anchors. To stabilize the price level, some nominal value must be fixed (anchored). If nominal wages are fixed by the government, real wages change with prices and output.

In principle, the nominal wage can be used as a nominal anchor. The exchange rate and price level would then change to achieve the real values and relative prices consistent with the fixed wage rate. For example, once wages are set, prices would adjust to match real costs of production to productivity. The exchange rate would adjust to clear the current and capital accounts at the equilibrium prices and costs of production. The money stock would respond to demand at the fixed money wage and equilibrium level of output and interest rate; money would grow (or decline) to support the equilibrium set of prices and inflation rate. 
Proposals for wage setting in Eastern Europe typically introduce a fixed exchange rate in addition to the fixed wage level [1]. Systems of this kind are inconsistent. There are now two fixed nominal values, one consistent with the nominal wage and one consistent with the money stock implied by the fixed exchange rate and decisions in the rest of the world. The real value of money in wage units is fixed, and the system cannot in general reach a stable equilibrium at full employment. There is inconsistency and, therefore, indeterminacy of equilibrium.

The indeterminacy can be removed if the exchange rate is devalued or revalued until the exchange rate and all other values are consistent with the real wage. In principle, an adjustment of this kind can be made, although in practice there is a problem of acquiring accurate information on which to base the decision without better private and social accounting. Without reliable information, it is not clear how the policy-maker would know where to set the exchange rate for consistency. And, the exchange rate would have to change whenever there are changes in the terms of trade, in factor productivities, or in any other determinant of equilibrium at home and abroad ${ }^{2}$.

Adjustment of the exchange rate by devaluing or revaluing solves one problem but introduces another. The system would be made mathematically consistent, but it would be subject to time inconsistency. People would learn that the exchange rate is not permanently fixed but is to be changed periodically. They would anticipate these changes and adjust prices and wages to reflect anticipated exchange rate changes. They would make errors in this process, introducing excess variability. This policy would not produce the socially most desirable outcome [3]. A better solution would be to allow the exchange rate to fluctuate if the money wage is fixed. With a freely fluctuating exchange rate the economy reaches equilibrium that is consistent and optimal for that policy rule. But, as suggested earli$\mathrm{er}$, a fluctuating exchange rate may introduce an excess burden of uncertainty during the transition to a market economy. The better course, then, would be to avoid wage controls.

\footnotetext{
2 See Table 1 for the experience in some Eastern European countries. Poland and Hungary devalued within the first two years.
}

\section{Selective Wage Controls}

Much of what has been said about general wage controls applies as well to selective wage controls with a fixed exchange rate. Equilibrium at full employment can only be assured if there is consistency between the relative prices of labor and foreign exchange. There is no reason to suppose this will be so under controls.

The system of selective wage controls and fixed exchange rate has been recommended to Eastern European economies by some of the principal international organizations (and other advisors). Poland is an example. Firms in the Polish state sector must pay a tax on wage increases above a fixed level. Since Polish prices are rising, real wages in the state sector fall. Other things equal, the fall in real wages induces a shift out of this sector. If the sector starts with excess labor relative to the equilibrium level that would prevail in a competitive market economy, the reallocation would be desirable. Whether the reallocation occurs depends also on the exchange rate which is fixed independently of the money wage. At the given exchange rate, some of the state industries may be induced to expand even if they do not earn competitive returns on capital, continue to receive subsidies, or do not pay taxes. Since the system with two fixed prices does not have a unique equilibrium, it is difficult to predict how the system adjusts.

Once again, achieving full employment equilibrium may require a change in the fixed money wage or in the exchange rate to remove the inconsistency. Until the change occurs, unemployment may be higher and the costs of transition larger than in a system without wage controls. Poland has devalued and has given up its fixed exchange rate for a crawling peg.

One of the arguments for selective wage control is that there is no competition, particularly for large state sector enterprises. These enterprises lack incentives to maximize profits, so workers or their representatives may demand and receive wage increases in excess of productivity. To avoid unemployment government is called upon to maintain subsidies to cover the losses. The additional spending would increase the budget deficit and raise money growth. This increases inflation, induces 
devaluation and possibly stagnation. As Poland shows, wage controls and a fixed exchange rate did not avoid this problem. As Russia shows, subsidies to state enterprises increase the risk of hyperinflation.

Must constraints be placed on wages until state firms are sold? I do not see why wage controls, or taxes on wage increases, should be a more effective discipline or a more efficient method of reducing excess employment in the state sector than a credible commitment to a fixed exchange rate, budget balance and imports of competing goods. If the Eastern European countries fix the exchange rate or establish a currency board, there is no mechanism for financing budget deficits by inflation. The commitment to a fixed exchange rate and monetary stability would be as credible as they can reasonably be made. Inflation could not be used to rescue workers even temporarily from the unemployment caused by their wage demands. Once workers learn this, the exchange rate will serve as the anchor. Competition from abroad would limit pricing decisions. There would be no inconsistency between wages and any other fixed nominal value with resulting unemployment or excess demand for labor.

The key is credibility. Credibility cannot be achieved by imposing wage controls. Credibility requires the institutional reforms outlined earlier that establish conditions for a market economy. These reforms are necessary but not sufficient. Policies must be stabilizing and must foster growth and efficiency, and the public must believe that this is so.

\section{Conclusion}

Economic theory does not provide a blueprint for the transition from socialism to a market economy. Pricing, production, location and distributional decisions under socialism are so far from market determined solutions that it is impossible to predict which industries and firms can adapt to earn competitive returns in a market economy. The only way to learn about the transition is to let the market work.

To work efficiently, the market requires institutions and structure. Private property, accounting and legal systems, and a monetary framework must be put in place. These reforms need not be complete, but there must be a path along which the rules and arrangements are expected to change. Without such a path, valuation of expected returns is guesswork about the future. A predictable path for property rights and institutions removes some of the guesswork.

The paper concentrates on decisions about the monetary framework, prices and wage setting. The first of these involves a choice between fixed and fluctuating exchange rates, or between control of exchange rates or control of money. Decisions about wage setting requires a decision about whether there should be restrictions on wage increases to supplement monetary or exchange rate control.

Economic theory gives a clear response to the second issue; wage control is inefficient and, in general, is inconsistent with control of money or exchange rates. If the exchange rate (money) is controlled, all prices and nominal values must adjust to the values implied by the exchange rate (money). This will be as true in transitional economies as in developed economies. Fixing another nominal value, the money wage or selected money wages, prevents the system from achieving equilibrium at full employment in general. The public must form anticipations about which price will adjust and about the timing and magnitude of the adjustment. This uncertainty is avoidable and, therefore, imposes an excess burden when it is present.

The choice between fixed and fluctuating rates has no general answer from theory. I argue that, for the transition, the choice should be between a permanently fixed exchange rate (perhaps a currency board) and a permanently fixed level of (base) money. By fixing one of these variables at least for the transition, the government signals its strong commitment to price stability.

The government cannot provide complete certainty, but it can make a more credible commitment to a fixed exchange rate by closing the monetary authority. A credible commitment to a fixed exchange rate or a fixed stock of money creates firm anticipations that prices will be relatively stable. Any subsidies must be paid from tax revenues or from saving. This encourages investment, including long-term investment to restructure the economy by 
foreigners and the domestic public. With fixed exchange rates, opening the economy to trade also imposes a set of relative prices for tradable goods. A clearing union in Eastern Europe would encourage trade and contribute to rational allocation and efficiency during the transition.

$M y$ analysis suggests that the international financial agencies erred in their proposals for transition and requirements for lending. They did not require that the economies in transition adopt relevant market institutions. These institutions are the source of the incentives that make markets work efficiently.

Two principles are involved: simultaneity and recursivity. All changes that are interdependent should be made at one time. For example, money, exchange rates, prices, wages, interest rates are all interdependent. Money cannot be controlled without closing the budget deficit, so fiscal reform must be part of the package of reforms. If some of these changes are made, while others are not, results are nonoptimal. Other changes must be made later. This is costly to the credibility of the reform program. My earlier discussion of wages and exchange rates illustrates this point.

Some reforms should precede the freeing of prices and the effort to reduce the budget deficit. There is a recursive relation between rules for contract, procedures for enforcing contracts, financial structure, accounting and valuation rules, or property rights and the type of market economy that results. The institutions of the market system are not much affected by the sets of prices that emerge, but the converse is not true. Rules and institutions influence the extent of competition, or the price elasticity of supply.

These rules do not imply that all state firms be sold before the market is allowed to function freely. Rules for valuation, contracts and rules for sale and distribution should precede the selling of state assets, but state firms cannot be valued without prices and interest rates. The plan for eliminating subsidies and selling state assets, once announced, will affect the prices of goods and services and therefore anticipations and valuations. The actual sale or realization, given the anticipation, is likely to have a smaller affect.

These principles lead to a different ordering than proposed by the international agencies. They appear to differ also from the sequences that have been adopted in Eastern Europe. I do not think these principles alone provide a framework. At most, they are a step toward development of such a framework to replace intelligent judgment, guess and the ad hoc procedures that have been used.

The early evidence suggests that where the rules for privatization and markets have been clearest as in the Czech Republic and Hungary - progress has been more rapid. Poland is in the middle and Russia slower to adopt a set of market rules. Here, too, the rate of progress (or its absence) seems to be ordered similarly.

Throughout I have neglected the political process and its interaction with the economy. As events in Russia and Romania suggest, economic reforms are more difficult to carry through if political reforms are incomplete. Again, economic analysis that neglects institutional constraints does not yield correct inferences or proper guidance.

\section{References}

[1] S. Fischer and A. Gelb, Issues in Socialist Economic Reform, Journal of Economic Perspectives, 5 (Fall) 1991, 91-106.

[2] S. Hanke and K. Schuler, Currency Boards for Eastern Europe. Washington: Heritage Foundation, (1991).

[3] F.E. Kydland and E.C. Prescott, Rules Rather than Discretion: The Inconsistency of Optimal Plans, Journal of Political Economy, 85, (June) 1977, pp. 473-492.

[4] M. Mussa, Nominal Exchange Rate Regimes and the Behavior of Real Exchange Rates: Evidence and Implications, Carnegie-Rochester Conference Series on Public Policy, 25, Autumn 1986, pp. 117-213.

[S] Anna J. Schwartz, Currency Boards: Their Past, Present, and Possible Future Role, Carnegie-Rochester Conference Series on Public Policy, 1993 (forthcoming).

[6] Economic Situation and Economic Reform in Eastern Europe, European Economy, Suppl. A., 8/9 Brussels, European Community, (Aug.-Sept.) 1992.

[7] A Survey of Eastern Europe, The Economist, 326, March 13,1993 , p. 9. 